\title{
Physiological Characterization and Molecular Identification of Denitrifying Bacteria Possesing Nitrous Oxide High Reduction Activity Isolated from Rice Soils
}

\author{
RATNA SETYANINGSIH ${ }^{1,2}$, IMAN RUSMANA ${ }^{1 *}$, PRIHASTO SETYANTO ${ }^{3}$, AND ANTONIUS SUWANTO ${ }^{1}$ \\ ${ }^{1}$ Department of Biology, Faculty of Mathematics and Natural Sciences, Institut Pertanian Bogor, Darmaga Campus, \\ Bogor 16680, Indonesia; 'Department of Biology, Faculty of Mathematics, and Natural Sciences, Universitas Sebelas Maret, \\ Jalan Ir Sutami 36 A, Kentingan, Surakarta 57126, Indonesia; ${ }^{3}$ Balai Penelitian Lingkungan Pertanian, \\ Jalan Jakenan-Jaken Km 05, Jakenan, Pati 59182, Indonesia
}

\begin{abstract}
Rice fields are one of the main sources of high nitrous oxide $\mathrm{N}_{2} \mathrm{O}$ emission. Soil denitrifiers possessing high $\mathrm{N}_{2} \mathrm{O}$ reduction activity are important for controlling $\mathrm{N}_{2} \mathrm{O}$ emission. Nitrous oxide reduction is the last step of denitrification process. The aims of this study were to characterize and to identify denitrifying bacteria isolated from rice soils possessing high activity of $\mathrm{N}_{2} \mathrm{O}$ reduction. Soil samples were taken from 6 locations of rice fields in Bogor (West Java) and Tangerang (Banten), Indonesia. Physiological characterization was performed using API $20 \mathrm{NE}$, while molecular identification was conducted based on the 16S rRNA gene sequence. It was found that ten isolates of denitrifying bacteria were able to grow using $\mathrm{N}_{2} \mathrm{O}$ as an electron acceptor as indicated by decreasing $\mathrm{N}_{2} \mathrm{O}$ concentration in the headspace of the cultures. The bacterial growth indicated by optical density, increased up to 0.12-0.47 after 5 days incubation. Isolate BL2 had the highest activity of $\mathrm{N}_{2} \mathrm{O}$ reduction followed by BL1 and BLN1 at up to $5.41,4.09$, and $3.91 \mu \mathrm{mol} \mathrm{mL}^{-1}$ bacterial cultures, respectively. The BL1, BL2, and BLN1 isolates had some different physiological characteristics. Based on their 16S rRNA sequence, BL1 and BLN1 were closely related to Ochrobactrum anthropi ATCC 49188 with similarity of $99 \%$.
\end{abstract}

Key words: denitrifying bacteria, $\mathrm{N}_{2} \mathrm{O}$ reduction, rice soils

Nitrous oxide is an environmentally important trace gas because of its contribution to global warming and its role in the destruction of the stratospheric ozone layer. $\mathrm{N}_{2} \mathrm{O}$ has 298 times higher global warming potential than that of carbon dioxide and it has 114 years atmospheric lifetime. The atmospheric $\mathrm{N}_{2} \mathrm{O}$ abundance has risen from $270 \mathrm{ppb}$ in 1750 to $319 \mathrm{ppb}$ in 2005 (Forster and Ramaswamy 2007). Rice fields are one of the main sources of high $\mathrm{N}_{2} \mathrm{O}$ emission. In irrigated rice fields, $\mathrm{N}_{2} \mathrm{O}$ is emitted simultaneously since the biochemistry of submerged soils support the production and emission of this gas (Majumdar 2003). The input of large amount of nitrogen fertilizer influences some microbial process especially nitrification and denitrification and results in increased production of $\mathrm{N}_{2} \mathrm{O}$ (Hayatsu et al. 2008).

The complete denitrification process leads to $\mathrm{N}_{2}$ formation while the incomplete denitrification produces $\mathrm{N}_{2} \mathrm{O}$. During the last step of complete denitrification, $\mathrm{N}_{2} \mathrm{O}$ is reduced to $\mathrm{N}_{2}$. A truncated version of denitrification is due to lack of activity or the absence of the gene for $\mathrm{N}_{2} \mathrm{O}$ reductase. Some denitrifying bacteria are able grow using $\mathrm{N}_{2} \mathrm{O}$ as the sole electron acceptor for oxidation of organic compounds (Zumft 1997). The composition of the end gas produced in denitrification varies among complete denitrifiers. Carlson and Ingraham (1983) reported that Pseudomonas stutzeri produced only $\mathrm{N}_{2}, P$. aeruginosa and Paracoccus denitrificans produced $\mathrm{N}_{2} \mathrm{O}$ as well, and under certain condition $P$. aeruginosa produced even more $\mathrm{N}_{2} \mathrm{O}$ than $\mathrm{N}_{2}$.

Differences in denitrifier community composition in soils affects $\mathrm{N}_{2} \mathrm{O}$ emission (Holtan-Hartwig et al. 2000). Denitrifying bacteria with the ability to reduce exogenous $\mathrm{N}_{2} \mathrm{O}$ may have an important role in determining the level of

*Corresponding author: Phone/Fax: +62-251-8622833; Email: irusmana@ipb.ac.id
$\mathrm{N}_{2} \mathrm{O}$ emission from the environment. The aims of this study were to characterize and to identify bacteria with a high $\mathrm{N}_{2} \mathrm{O}$ reduction activity from rice soils. These study represent a preliminary research to obtain potential bacteria isolates to reduce $\mathrm{N}_{2} \mathrm{O}$ emission in rice fields.

\section{MATERIALS AND METHODS}

Soil Samples and Media. Soil samples were taken from 6 locations of rice fields in Bogor (West Java) and Tangerang (Banten), Indonesia. Truncated $2.5 \mathrm{~mL}$ syringes capped with a rubber seal were used for collecting soil samples. Experiments were conducted using denitrification media containing: $2.72 \mathrm{~g} \mathrm{CH}_{3} \mathrm{COONa} \cdot 3 \mathrm{H}_{2} \mathrm{O}, 0.8 \mathrm{~g} \mathrm{~K}_{2} \mathrm{HPO}_{4}, 0.3 \mathrm{~g}$ $\mathrm{KH}_{2} \mathrm{PO}_{4}, 0.4 \mathrm{~g} \mathrm{NH}_{4} \mathrm{Cl}, 5.2 \mathrm{~g} \mathrm{MgSO}_{4} \cdot 7 \mathrm{H}_{2} \mathrm{O}, 1 \mathrm{~L}$ aquadest (Barford et al. 1999) and added with $2.55 \mathrm{~g} \mathrm{NaNO}_{3}$ and $2 \mathrm{~mL}$ trace element. The trace element composition was $50 \mathrm{~g} \mathrm{NaEDTA}, 1.407 \mathrm{~g} \mathrm{ZnCl}_{2}, 5.5 \mathrm{~g} \mathrm{CaCl}_{2}, 5.06 \mathrm{~g} \mathrm{MnCl}_{2} \cdot 4 \mathrm{H}_{2} \mathrm{O}$, $\left.4.86 \mathrm{~g} \mathrm{FeCl}_{3} \cdot 6 \mathrm{H}_{2} \mathrm{O}, 1.1 \mathrm{~g} \mathrm{(NH}\right)_{4} \mathrm{Mo}_{7} \mathrm{O}_{24} \cdot 4 \mathrm{H}_{2} \mathrm{O}, 1.57 \mathrm{~g} \mathrm{CuSO}_{4}$. $5 \mathrm{H}_{2} \mathrm{O}, 1.61 \mathrm{~g} \mathrm{CoCl}_{2} \cdot 6 \mathrm{H}_{2} \mathrm{O}, 1 \mathrm{~L}$ aquadest.

Bacterial Isolation. Thirty $\mathrm{mL}$ sterile media in $70 \mathrm{~mL}$ serum bottles sealed using rubber seals were used to grow bacteria. Anaerobic conditions were achieved by flushing sterile $\mathrm{N}_{2}$ gas into the bottles for $10 \mathrm{~min}$. One millilitre soil suspension (five times dilution) was injected aseptically into the bottles. The cultures were incubated at room temperature $\left(28-30^{\circ} \mathrm{C}\right)$ for $5-7$ days. The bacteria were isolated using streak method on agar media and incubated either anaerobically (in an anaerobic chamber) or aerobically at room temperature $\left(28-30^{\circ} \mathrm{C}\right)$ for 7 days. Separately growing colonies were purified by streaking on fresh agar media. The pure isolates were tested for their ability to perform oxidative or fermentative metabolisms using Hugh and Leifson (1953) method. The isolates performing oxidative metabolism were selected for further experiment. 
Bacterial Growth and Nitrous Oxide Reduction Test. The selected isolates were grown anaerobically in $7 \mathrm{~mL}$ liquid media without $\mathrm{No}_{3}{ }^{-}$in test tubes capped with rubber seals. Nitrous oxide was added to the headspace using sterile syringe to obtain a final concentration of $3.54 \mu \mathrm{mol} \mathrm{mL} \mathrm{m}^{-1}$ headspace volume. The inoculum used $(2 \%, \mathrm{v} / \mathrm{v})$ was a culture in exponential growth $\left(\mathrm{OD}_{\lambda 550 \mathrm{~mm}} 0.6\right)$. Incubation was conducted for 5 on a shaker at room temperature $\left(28-30^{\circ} \mathrm{C}\right)$. Bacterial growth was measured turbidimetrically using a Bausch and Lomb Spectronic 20 spectrophotometer at 550 $\mathrm{nm}$ and headspace $\mathrm{N}_{2} \mathrm{O}$ concentration were analysed using Shimadzu gas chromatography-14B with electron capture detector (ECD). Sterile medium without bacteria added with $\mathrm{N}_{2} \mathrm{O}$ was used as a control.

Characterization and Identification. Bacterial isolates were examined using light microscope and their characteristics i.e. colour, elevation, margin, and shape of colony; also shape and motility of cells were recorded. In addition, isolates were characterized on the basis of Gram staining. Physiological characterization was performed using API 20 NE (Biomérieux). Molecular identification was carried out based on $16 \mathrm{~S}$ rRNA sequence. Deoxyrobonucleic acid (DNA) extraction was done according to Lazo et al. (1987).

Amplification of 16S rRNA genes was performed using polymerase chain reaction (Perkin Elmer GeneAmp PCR System). Amplification was carried out using GoTaq Flexi DNA Polymerase (Promega) with the primers $63 \mathrm{f}$ (5'-CAG GCC TAA CAC ATG CAA GTC) and 1387r (5'-GGG CGG WTG GTA CAA GGC) (Marchesi et al. 1998). The thermalcycling conditions were initial denaturation step at $95^{\circ} \mathrm{C}$ for $5 \mathrm{~min}$; followed by 30 cycles of $95^{\circ} \mathrm{C}$ for $30 \mathrm{~s}, 55^{\circ} \mathrm{C}$ for 1 $\min , 72^{\circ} \mathrm{C}$ for $1 \mathrm{~min}$; and a final extension step at $72^{\circ} \mathrm{C}$ for 5 min. The nucleotide sequence of the PCR products were determined using an ABI PRISM 3100-Avant Genetic Analyzer (Applied Biosystems, USA) 4 capillary and Big Dye Terminator cycle sequencing kit v3.1 (Applied Biosystems, USA). Sequence data were compared with sequences in The National Centre for Biotechnology Information (NCBI) (http://www.ncbi.nlm.nih.gov) data bank using Basic Local Alignment Search Tool (BLAST). A phylogenetic tree was constructed using Molecular Evolutionary Genetic Analysis (MEGA) version 4.0 program (Tamura et al. 2007).

\section{RESULTS}

Bacterial Isolates. Twenty four bacteria were isolated from 6 sampling locations using $\mathrm{NO}_{3}{ }^{-}$enrichment media. Soil sample $\mathrm{pH}$ was between 5 and 6 . Ten isolates were obtained under aerobic condition and the remaining 14 isolates were isolated anaerobically. Fifteen isolates showed oxidative metabolism, while 9 isolates showed fermentative metabolism (Table 1). The oxidative isolates were considered as denitrifying bacteria and selected for further study.

Bacterial Growth and $\mathbf{N}_{\mathbf{2}} \mathrm{O}$ Reduction. As many as 10 isolates were tested for their ability to use $\mathrm{N}_{2} \mathrm{O}$ (Table 2).
BL2 isolate showed the highest $\mathrm{N}_{2} \mathrm{O}$ reduction activity among tested isolates, although the growth of $\mathrm{BL} 1, \mathrm{Sg} 1$, and BLN1 were faster than that of B12. BL2 isolate could reduce up to $5.41 \mu \mathrm{mol} \mathrm{mL} \mathrm{m}^{-1}$ bacterial culture of the $\mathrm{N}_{2} \mathrm{O}$ after 5 of incubation at room temperature $\left(28-30^{\circ} \mathrm{C}\right)$ followed by BL1 and BLN1 isolates which could reduce up to 4.09 and $3.91 \mu \mathrm{mol} \mathrm{mL}{ }^{-1}$ bacterial cultures of the $\mathrm{N}_{2} \mathrm{O}$ respectively. The $\mathrm{N}_{2} \mathrm{O}$ reductions of other isolates varied between 1.02$3.55 \mu \mathrm{mol} \mathrm{mL} L^{-1}$ bacterial cultures of the $\mathrm{N}_{2} \mathrm{O}$.

Characteristics and Identity of Bacteria. The morphology of three selected colonies possessing high $\mathrm{N}_{2} \mathrm{O}$ reduction activity (BL1, BL2, and BLN1) was cream in colour, convex elevation, and entire margin. BL1 and BLN1 colonies were circular, while BL2 was ellipse. Cells were

Table 1 Bacteria isolated from samples of rice soils in Bogor and Tangerang

\begin{tabular}{|c|c|c|c|c|}
\hline $\begin{array}{l}\text { Sampling } \\
\text { locations }\end{array}$ & $\begin{array}{l}\text { Soil } \\
\text { pH }\end{array}$ & Isolates & $\begin{array}{l}\text { Growth } \\
\text { conditions }\end{array}$ & Metabolisms \\
\hline \multicolumn{5}{|l|}{ Bogor } \\
\hline \multirow[t]{2}{*}{ Leuwisadeng } & 5.5 & LSN1 & Anaerobe & Oxidative \\
\hline & & LSN2 & Anaerobe & Oxidative \\
\hline \multirow[t]{5}{*}{ Sipak } & 5.0 & SP1 & Aerobe & Fermentative \\
\hline & & SP2 & Aerobe & Fermentative \\
\hline & & SPN1 & Anaerobe & Fermentative \\
\hline & & SPN3 & Anaerobe & Fermentative \\
\hline & & SPN4 & Anaerobe & Fermentative \\
\hline \multirow[t]{8}{*}{ Situgede } & 6.0 & SG1 & Aerobe & Oxidative \\
\hline & & SG2 & Aerobe & Oxidative \\
\hline & & SGN1 & Anaerobe & Oxidative \\
\hline & & SGN3 & Anaerobe & Oxidative \\
\hline & & SGN4 & Anaerobe & Oxidative \\
\hline & & SGN5 & Anaerobe & Oxidative \\
\hline & & SGN6 & Anaerobe & Oxidative \\
\hline & & SGN7 & Anaerobe & Oxidative \\
\hline \multirow{4}{*}{$\begin{array}{l}\text { Situgede } \\
\text { (seedbed) }\end{array}$} & 6.0 & SS1 & Aerobe & Fermentative \\
\hline & & $\mathrm{SS} 2$ & Aerobe & Oxidative \\
\hline & & SS3 & Aerobe & Fermentative \\
\hline & & SSN1 & Anaerobe & Fermentative \\
\hline \multicolumn{5}{|l|}{ Tangerang } \\
\hline \multirow[t]{4}{*}{ Belendung } & 5.0 & BL1 & Aerobe & Oxidative \\
\hline & & BL2 & Aerobe & Oxidative \\
\hline & & BLN1 & Anaerobe & Oxidative \\
\hline & & BLN2 & Anaerobe & Oxidative \\
\hline Cipete & 5.5 & CP1 & Aerobe & Fermentative \\
\hline
\end{tabular}

Table 2 Growth and $\mathrm{N}_{2} \mathrm{O}$ reduction of denitrifier isolates incubated in 5 days at room temperature $\left(28-30^{\circ} \mathrm{C}\right)^{a}$

\begin{tabular}{|c|c|c|}
\hline Isolates & $\begin{array}{c}\text { Growth } \\
\left(\mathrm{OD}_{\lambda 550 \mathrm{~nm}}\right)\end{array}$ & $\begin{array}{c}\mathrm{N}_{2} \mathrm{O} \text { reduced } \\
\left(\mu \mathrm{mol} \mathrm{mL} \mathrm{m}^{-1} \text { culture }\right)\end{array}$ \\
\hline SG1 & $0.45 \pm 0.00$ & $3.55 \pm 0.23$ \\
\hline $\mathrm{SS} 2$ & $0.37 \pm 0.02$ & $1.30 \pm 0.00$ \\
\hline BL1 & $0.47 \pm 0.00$ & $4.09 \pm 0.92$ \\
\hline BL2 & $0.39 \pm 0.03$ & $5.41 \pm 0.03$ \\
\hline LSN1 & $0.25 \pm 0.02$ & $1.33 \pm 0.00$ \\
\hline LSN2 & $0.20 \pm 0.10$ & $1.02 \pm 0.00$ \\
\hline SGN4 & $0.35 \pm 0.01$ & $1.02 \pm 0.04$ \\
\hline SGN6 & $0.12 \pm 0.01$ & $1.11 \pm 0.00$ \\
\hline SGN7 & $0.21 \pm 0.02$ & $1.51 \pm 0.04$ \\
\hline BLN1 & $0.43 \pm 0.01$ & $3.91 \pm 0.12$ \\
\hline
\end{tabular}

${ }^{a}$ Initial concentration of $\mathrm{N}_{2} \mathrm{O}$ was $3.54 \mu \mathrm{mol} \mathrm{mL}^{-1}$ headspace volume 
rod-shaped, motile, and Gram negative. Based on the API 20 NE assay (Table 3), the three isolates had different physiological characters on hydrolysis of esculine and Pnitrophenyl- $\beta$-D-galactopyranoside, and also for the assimilation of potassium gluconate and trisodium citrate. From their physiological characters, BLN1 isolate was identified as Ochrobactrum anthropi with $99.9 \%$ similarity, while the profiles of B11 and BL2 isolates were unknown. However based on 16S rRNA sequences analysis using BLAST (500 bp), BL1, BL2, and BLN1 isolates had similarity of 99,95 , and $99 \%$ respectively with $O$. anthropi ATCC 49188 (accession number NC 009668) (Table 4). The phylogenetic tree of the 16S rRNA gene sequence of the isolates shows that BL1, BL2, and BLN1 are members of Alphaproteobacteria and the same class with Ochrobactrum, Azospirillum brasilense and Azhorhizobium caulinodans (Fig 1).

\section{DISCUSSION}

This study has shown that denitrifying bacteria possessing $\mathrm{N}_{2} \mathrm{O}$ reduction activity could be isolated from rice soils. Denitrifiers were isolated under both aerobic and anaerobic isolation conditions. Denitrification is exclusively a facultatively anaerobic or microaerophilic trait. Its expression is triggered in the cell by the low environmental oxygen tension and the availability of a nitrogen oxide. Anaerobically grown cells do not lose their capacity to respire oxygen (Zumft 1997). Some bacteria can carry out the denitrifying process on varying of oxygen levels. However, oxygen has an effect on the denitrification rate and gas end product ratio (Davies et al. 1989; Takaya et al. 2003). Most denitrifying bacteria are incapable of growing anaerobically by fermentative metabolism (Garcia and Tiedje 1982). Thus, the referred fermentative isolates were not denitrifier.
Table 3 Physiological characteristics of BL1, B12, and BLN1 isolates

\begin{tabular}{|c|c|c|c|}
\hline Physiological tests & BL1 & BL2 & BLN1 \\
\hline Reduction of nitrate & + & + & + \\
\hline Indole production & - & - & - \\
\hline Glucose fermentation & - & - & - \\
\hline \multicolumn{4}{|l|}{ Hydrolysis } \\
\hline Arginine & + & + & + \\
\hline Urea & + & + & + \\
\hline Esculine & + & + & - \\
\hline Gelatine & - & - & - \\
\hline $\begin{array}{l}\text { p-nitrophenyl- } \beta \text {-D- } \\
\text { galactopyranoside }\end{array}$ & + & - & - \\
\hline \multicolumn{4}{|l|}{ Assimilation } \\
\hline D-glucose & + & + & + \\
\hline L-arabinose & + & + & + \\
\hline D-mannose & + & + & + \\
\hline D-mannitol & - & - & - \\
\hline $\mathrm{N}$-acetyl glucosamine & + & + & + \\
\hline D-maltose & + & + & + \\
\hline Potassium gluconate & + & - & - \\
\hline Capric acid & - & - & - \\
\hline Adipic acid & - & - & - \\
\hline Malic acid & + & + & + \\
\hline Trisodium citrate & + & - & + \\
\hline Phenylacetic acid & - & - & - \\
\hline Oxidase test & + & + & + \\
\hline
\end{tabular}

Table 4 Identification results of BL1, B12, and BLN1 isolates based on API $20 \mathrm{NE}$ tests and $16 \mathrm{~S}$ rRNA sequences

\begin{tabular}{llc}
\hline Isolates & API 20 NE test & $\begin{array}{l}\text { 16S rRNA } \\
\text { sequences }\end{array}$ \\
\hline BL1 & Unknown & $\begin{array}{l}\text { O. anthropi ATCC 49188 } \\
(99 \%)\end{array}$ \\
BL2 & Unknown & O. anthropi ATCC 49188 \\
BLN1 & Ochrobactrum anthropi & $(95 \%)$ \\
& $(99.9 \%)$ & O. anthropi ATCC 49188 \\
& & $(99 \%)$ \\
& & \\
\hline
\end{tabular}

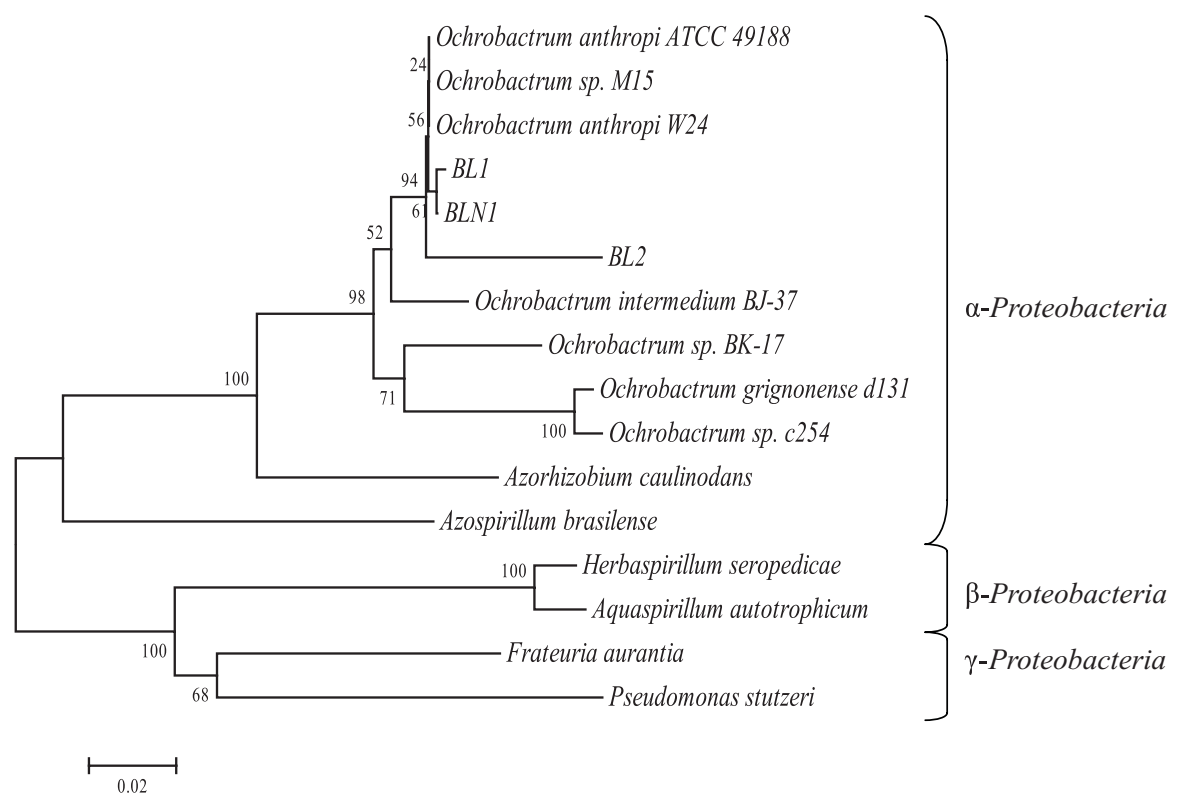

Fig 1 Neighbour-joining dendrogram derived from 16S rRNA gene sequences of the bacteria isolated from rice soils and other bacteria members of the phylum Proteobacteria. The scale bar represents $2 \%$ sequence divergence. Bootstrap test was conducted by 500 replicates. 
All tested isolates could grow using exogenous $\mathrm{N}_{2} \mathrm{O}$ so that $\mathrm{N}_{2} \mathrm{O}$ concentration in the headspace was decreased while OD of cells was increased. Nitrous oxide reduction was coupled to electron transport phosphorylation and thereby to cell growth. However, the ability to grow on $\mathrm{N}_{2} \mathrm{O}$ varied among the isolates tested. Snyder et al. (1987) suggested that synthesis and destruction of enzyme may be the mechanisms that control $\mathrm{N}_{2} \mathrm{O}$ reductase activity. Not all denitrifiers can reduce exogenous $\mathrm{N}_{2} \mathrm{O}$ to $\mathrm{N}_{2}$ efficiently. Bazylinski et al. (1986) reported that $P$. aeruginosa $\mathrm{P} 2$ grew abundantly on exogenous $\mathrm{N}_{2} \mathrm{O}$ but the exogenous $\mathrm{N}_{2} \mathrm{O}$ had little effect on the cell yields of PAO1 and P1 strains. According to Snyder et al. (1987), the inability of a number of $P$. aeruginosa strains to grow well on $\mathrm{N}_{2} \mathrm{O}$ is therefore a consequence of the nearly complete loss of $\mathrm{N}_{2} \mathrm{O}$ reductase activity.

The high similarities (99\%) among BL1 and BLN1 with O. anthropi ATCC 49188 indicate that these isolates are closely related to the bacterium. Isolate BL2 may be a new species in genus Ochrobactrum because it has $95 \%$ similarity with $O$. anthropi ATCC 49188 . The most widely accepted definition is that strains with over $97 \%$ similarity over entire gene are the same species (Stackebrandt and Goebel 1994). Aside of being closely related to O. anthropi ATCC 49188, in phylogenetic tree BL1 and BLN1 isolates also closely related to Ochrobactrum sp. M15 and Ochrobactrum anthropi $\mathrm{W} 24$ used as comparators (Fig 1).

From this study, 10 isolates of $\mathrm{N}_{2} \mathrm{O}$ reducing denitrifier have been obtained from rice soils. Two of three isolates identified were closely related to $O$. anthropi ATCC 49188. Genus Ochrobactrum is member of family Brucellaceae, order Rhizobiales, class Alphaproteobacteria (Garrity and Holt 2001). According to Zumft (1997) denitrification carried out by a diversity of bacteria taxonomically belonging to the group of Proteobacteria. In the rice soil with strong denitrification activity, Ishii et al. (2009) found that the dominant bacteria were members of Bukholderiales and Rhodocyclales (Betaproteobacteria).

Bacteria with high $\mathrm{N}_{2} \mathrm{O}$ reduction activity have the potential application to regulate $\mathrm{N}_{2} \mathrm{O}$ emission in rice fields. Three isolates that showed high $\mathrm{N}_{2} \mathrm{O}$ reduction activity have been selected in this study. Nevertheless, some experiments still needed to measure the $\mathrm{N}_{2} \mathrm{O}$ reduction activity in more detail, at laboratory and also at the field scale.

\section{ACKNOWLEDGEMENT}

This research was supported by BPPS scholarship grant from DIKTI to the first author.

\section{REFERENCES}

Barford CC, Montoya JP, Altabet MA, Mitchell R. 1999. Steady-state nitrogen isotope effects of $\mathrm{N}_{2}$ and $\mathrm{N}_{2} \mathrm{O}$ production in Paracoccus denitrificans. Appl Environ Microbiol 65:989-94.
Bazylinski DA, Soohoo CK, Hollocher TC 1986. Growth of Pseudomonas aeruginosa on nitrous oxide. Appl Environ Microbiol 51:1239-46.

Carlson CA, Ingraham JL. 1983. Comparison of denitrification by Pseudomonas stutzeri, Pseudomonas aeruginosa and Paracoccus denitrificans. Appl Environ Microbiol 45:1247-53.

Davies KJP, Llyod D, Boddy L. 1989. The effect of oxygen on denitrification in Paracoccus denitrificans and Pseudomonas aeruginosa. J Gen Microbiol 135:2445-51.

Forster P, Ramaswamy V. 2007. Change in atmospheric constituents and radiative forcing. In: Solomon S, Qin D, Manning $\mathrm{M}$, Marquis $\mathrm{M}$, Averyt K, Tignor MMB, Miller Jr. HL, Chen Z, editors. Climate change: the physical science basis. New York: Cambridge University Pr, p 141-3.

Garcia JL, Tiedje JM. 1982. Denitrification in rice soils. In: Dommergues YR, Diem HG, editors. Microbiology of tropical soils and plant productivity. Boston: Martinus Nijhoff Publ. p 190-1.

Garrity GM, Holt JG. 2001. The road map to the manual. In: Boone DR, Castenholz RW, editors. Systematic bacteriology. $2^{\text {nd }}$ ed. New York: Springer. p 157-9.

Hayatsu M, Tago K, Saito M. 2008. Various players in the nitrogen cycle: diversity and functions of the microorganisms involved in nitrification and denitrification. Soil Sci Plant Nutr 54:33-45.

Holtan-Hartwig L, Dörsch P, Bakken LR. 2000. Comparison of denitrifying communities in organic soils: kinetics of $\mathrm{NO}_{3}^{-}$and $\mathrm{N}_{2} \mathrm{O}$ reduction. Soil Biol Biochem 32:833-43.

Hugh R, Leifson E. 1953. The taxonomic significance of fermentative versus oxidative metabolism of carbohydrates by various Gram negative bacteria. J Bacteriol 66:24-6.

Ishii S, Yamamoto M, Kikhuci M, Oshima K, Hattori M, Atsuka S, Senoo K. 2009. Microbial population responsive to denitrification-inducing conditions in rice paddy soil, as revealed by comparative 16S rRNA gene analysis. Appl Environ Microbiol 75:7070-8.

Lazo GR, Roffey R and Gabriel DW. 1987. Pathovar of Xanthomonas campestris are distinguishable by restriction fragment-length polymorphism. Int J Syst Bacteriol 37: 214-21.

Majumdar D. 2003. Methane and nitrous oxide emission from irrigated rice fields: proposed mitigation strategies. Curr Sci 84:1317-26.

Marchesi JR, Sato T, Weightman AJ, Martin TA, Fry JC, Hiom SJ, Dymok D, Wade WG. 1998. Design and evaluation of useful bacteriumspecific PCR primer that amplify genes coding for bacterial 16 S rRNA. Appl Environ Microbiol 64:795-9.

Snyder SW, Bazylinski DA, Hollocher, TC. 1987. Loss of $\mathrm{N}_{2} \mathrm{O}$ reductase activity as an explanation for poor growth of Pseudomonas aeruginosa on $\mathrm{N}_{2} \mathrm{O}$. Appl Environ Microbiol 53:2045-9.

Stackebrandt E, Goebel BM. 1994. Taxonomic note: a place for DNADNA reassociation and $16 \mathrm{~S}$ rRNA sequence analysis in the present species definition in bacteriology. Int J Systematic Evol Microbiol 4:846-9.

Takaya N, Catalan-Sakairi MAB, Sakaguchi Y, Kato I, Zhou Z, Shoun H. 2003. Aerobe denitrifying bacteria that produce low levels of nitrous oxide. Appl Environ Microbiol 69:3152-7.

Tamura K, Dudley J, Nei M, Kumar S. 2007. MEGA 4: molecular evolutionary genetic analysis (MEGA) software version 4.0. Mol Biol Evol 24:1596-9.

Zumft WG. 1997. Cell biology and molecular basis of denitrification. Microbiol Mol Biol Rev 61:533-616. 